\title{
Bacteriological and Physicochemical Analyses of the Raw and Treated Water of Saidabad Water Treatment Plant, Dhaka
}

\author{
MAlamgir Hossain ${ }^{1 *}$, Tahmina Begum ${ }^{1}$, ANM Fakhruddin ${ }^{2}$ and Sirajul Islam Khan ${ }^{3}$ \\ ${ }^{1}$ Saidabad Water Treatment Plant (SWTP), Dhaka WASA, Dhalpur, Dhaka 1204, Bangladesh, ${ }^{2}$ Institute of Food \& Radiation Biology, Atomic Energy \\ Research Establishment, Ganakbari, Saver, GPO Box 3787, Dhaka 1000, Bangladesh, ${ }^{3}$ Department of Microbiology, University of Dhaka, Dhaka \\ 1000, Bangladesh
}

[Received 28 August 2006; Accepted 07 October 2006]

\begin{abstract}
Bacteriological and physicochemical parameters of the raw and treated water of the Saidabad Water Treatment Plant were analysed during the period January through December 2004. It was found that during dry season Sitalakhya River water was adversely polluted and most of the bacteriological and physicochemical parameters increased to an alarming level. Total coliform and thermotolerant-coliform counts of raw water were highest in months of January through March and lowest during the months of April through November. Ammonia concentration of the raw water was very high (3.08-7.06 mg/l) during the dry months from January to April that coincided with high (2.57-6.08 mg/l) ammonia contamination in the treated water. The others physicochemical parameters like turbidity, conductivity, total dry solid (TDS), hardness and alkalinity were high during the dry months. The residual chlorine in treated water was always below $0.50 \mathrm{mg} / \mathrm{l}$. The study clearly indicated that the load of coliform increased when the concentration of ammonia was high in raw water that, to some extent, influenced the aesthetic properties of the treated water like turbidity, colour, taste, odour, alkalinity, TDS, etc. In spit of that the treated water could be used for domestic and drinking purposes for most of the year.
\end{abstract}

Keywords: Water quality, Total coliform, Thermotolerant-coliform, Ammonia, Physicochemical properties, Residual chlorine

\section{Introduction}

Water quality is an extensive research area since water is an important vehicle for the transmission of various microorganisms, including pathogenic bacteria, viruses, parasites as well as chemical pollutants. Water and sanitation condition is mostly poor in developing countries including Bangladesh. Insufficient treatment of domestic sewage is one of the major reasons for the degradation of water environment ${ }^{1}$. An estimated $80 \%$ of all diseases are water-related and on average, as much as one-tenth of each person's productive time is sacrificed to water-related diseases ${ }^{2}$. About $20-30 \%$ of mortality in Bangladesh occurs due to water-borne diseases, e.g., diarrhoea, dysentery, gastroenteritis ${ }^{3}$. So safe water supply is very important to cut down the incidence of water-borne diseases.

Saidabad Water Treatment Plant (SWTP) is a surface water treatment plant. The Sitalakhya River is the source of the raw water for the plant. Different treatment processes like prechlorination, coagulation, filtration, disinfection and $\mathrm{pH}$ correction are used at SWTP. There is paucity of information regarding the microbiological and chemical quality of the raw water as well as treated water of SWTP since its operation in July 2002. The aims of the present investigation were to assess the bacteriological and physicochemical parameters of the raw as well as treated water on a seasonal basis.

\section{Materials and Methods}

\section{Water samples}

The study was conducted during the period of January through December 2004. Water samples, from inlet point (raw water from the river Sitalakhya) and outlet point (treated water) of the Saidabad Water Treatment Plant (SWTP), Dhaka, were collected in sterile glass bottles for weekly bacteriological and physicochemical analyses. Samples, kept at $4^{\circ} \mathrm{C}$, were analysed without much delay to avoid any alteration. They were divided into two parts. One part was used for immediate bacteriological analyses, and the second part was used for physicochemical analyses.

\section{Bacteriological analyses}

Total coliform and thermotolerant-coliform counts were conducted by modified membrane filter counting technique ${ }^{4}$. From each bottle

*Corresponding author:

M Alamgir Hossain, Microbiologist, Saidabad Water Treatment Plant, Dhaka WASA, Dhalpur, Dhaka 1204, Bangladesh Tel (Office): (02) 7544761/205, Cell: 0152 444693; E-mail: alamh2002@yahoo.com 
$100 \mathrm{ml}$ of water was passed aseptically through sterile millipore filter papers (porosity of $0.45 \mu \mathrm{m}$ ) to isolate the microorganisms present in the water samples. The filter papers were then aseptically transferred to three replicate plates containing m-ENDO agar media (Difco, USA) and $\mathrm{mFC}$ agar (Difco, USA) for recovering and counting of total coliform and thermotolerant-coliform bacteria respectively. The plates were incubated at $37^{\circ}$ and $44.5^{\circ} \mathrm{C}$ up to $48 \mathrm{~h}$ for the growth of coliform and thermotolerant-coliform respectively. Colonies were counted from responsive plates and expressed as $\mathrm{cfu} / 100 \mathrm{ml}$.

\section{Physicochemical analyses}

Turbidity of the samples was determined with a turbidity meter (Model WTW, Turb-550, USA). pH values of the samples were determined with a digital $\mathrm{pH}$ meter (Model sensION2, HACH, USA). Electrical conductivity (EC) and total dry solid (TDS) were measured with a conductivity meter (Model sensION7 HACH, USA.). Samples were filtered through membrane filter with porosity of $0.45 \mu \mathrm{m}$ (Sartorius, Minisart, Germany) and then the colour was recorded by a spectrophotometer (Model DR/2500, Odyssey, HACH, USA.) according to the standard methods ${ }^{4}$. Total hardness and total alkalinity were determined using standard titrimetric methods ${ }^{5-6}$. Ammonia-N, iron, residual chlorine and total chlorine were determined by spectrophotometer according to the standard procedures ${ }^{4}$.

\section{Results and Discussion}

Figure 1 depicted the total coliform counts of the raw and treated water of Saidabad Water Treatment Plant (SWTP) during the year 2004. Seasonal variation in bacteriological counts was found in raw water. The average maximum and minimum values of total coliforms for the raw water were $3.78 \log _{10} \mathrm{cfu} / 100 \mathrm{ml}$ in March and $3.0 \log _{10} \mathrm{cfu} / 100 \mathrm{ml}$ in November respectively. On the other hand, the average maximum and minimum values of the thermotolerant-coliform for the raw water were $3.0 \log _{10} \mathrm{cfu} / 100 \mathrm{ml}$ in March and $2.0 \log _{10} \mathrm{cfu} / 100 \mathrm{ml}$ in August respectively (Figure 2). An increasing trend of thermotolerant-coliform was found during January to March, and a sharp dropdown was observed during April to November. The source of the raw water of SWTP was the river Sitalakheya that receives domestic sewage as well as industrial effluents from the adjacent arrears of Dhaka city ${ }^{7}$. No coliforms or thermotolerant-coliforms were detected at anytime in the treated water over the study period. This indicates that the treatment system of SWTP was effective in removal of harmful water-borne pathogens.

Physicochemical factors are very important aspects of potable of water. Certain range of these factors enhances the bacterial growth and it also determines the sanitary quality of water. Seasonal variation of physicochemical factors of raw and treated water of

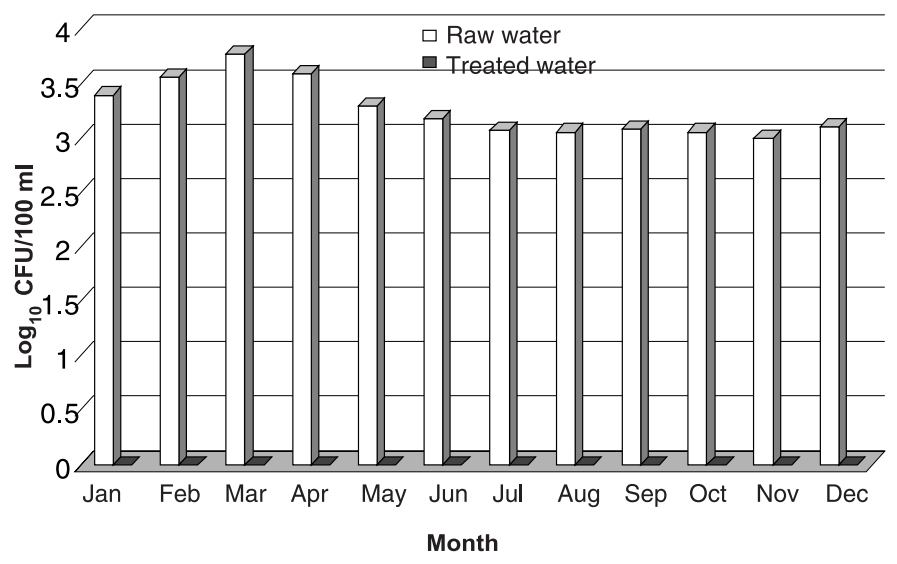

Figure 1. Seasonality of average total coliform counts of raw and treated water of Saidabad Water Treatment Plant (SWTP) in the year 2004.

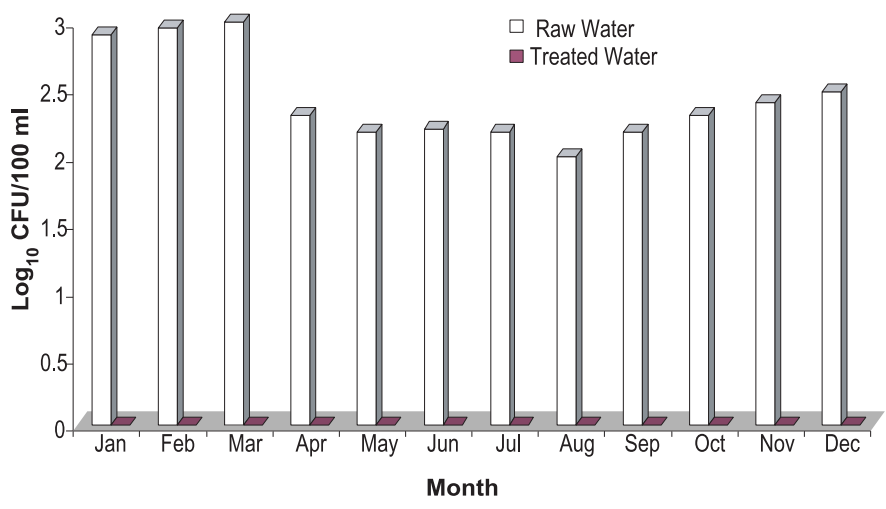

Figure 2. Seasonality of average thermotolerant-coliform counts of raw and treated water of Saidabad Water Treatment Plant (SWTP) in the year 2004.

SWTP is summarized in Table 1 and 2 respectively. There were some fluctuations of the raw water $\mathrm{pH}$ over the period from January to December; the minimal value ( $\mathrm{pH}$ 6.87) was recorded in June and the maximum ( $\mathrm{pH}$ 7.46) in March. The maximum $\mathrm{pH}$ of treated water was 7.41 in December and the minimum was 6.99 in June. The $\mathrm{pH}$ values were well within the acceptable range $(\mathrm{pH} 6.5$ to 8.5 of WHO specification ${ }^{8}$. Small changes in $\mathrm{pH}$ might be the cause of significant changes in other qualities like solubility of iron, manganese, copper, calcium, and other metals ${ }^{9}$. There were small fluctuations of the raw water turbidity from June to September, and it was relatively stable and low during the winter and the dry seasons. The turbidity of treated water was maintained low and well under the WHO guideline value (5 of NTU) during the study period ${ }^{8}$. Turbidity in water was due to the presence of suspended colloidal particles such as clay, silt, finely divided organic matter, plankton and other microscopic organisms. The colour of the treated water was almost always found within the WHO permissible level (15 TCU). 
Table 1. Seasonal variation of physicochemical parameters of raw water of Saidabad Water Treatment Plant (SWTP) in the year 2004

\begin{tabular}{|c|c|c|c|c|c|c|c|c|c|}
\hline Month* & $\mathrm{pH}$ & $\begin{array}{c}\text { Turbidity } \\
\text { (NTU) }\end{array}$ & $\begin{array}{c}\text { Colour } \\
\text { (TCU) }\end{array}$ & $\begin{array}{l}\text { Conductivity } \\
(\mu \mathrm{S} / \mathrm{cm})\end{array}$ & $\begin{array}{l}\text { TDS } \\
(\mathrm{mg} / \mathrm{l})\end{array}$ & $\begin{array}{c}\text { Total } \\
\text { alkalinity } \\
\left(\mathrm{mg} / \mathrm{l} \text { as } \mathrm{CaCO}_{3}\right)\end{array}$ & $\begin{array}{c}\text { Total } \\
\text { hardness } \\
\left(\mathrm{mg} / 1 \text { as } \mathrm{CaCO}_{3}\right)\end{array}$ & $\begin{array}{c}\mathrm{Fe} \\
(\mathrm{mg} / \mathrm{l})\end{array}$ & $\begin{array}{c}\mathrm{NH}_{3}-\mathrm{N} \\
(\mathrm{mg} / \mathrm{l})\end{array}$ \\
\hline January & 7.39 & 4.7 & 14 & 380 & 195 & 173 & 145 & 0.12 & 3.67 \\
\hline February & 7.39 & 7.2 & 31.3 & 430 & 220 & 225 & 177 & 0.13 & 6.24 \\
\hline March & 7.46 & 8.3 & 21.5 & 500 & 254 & 230 & 170 & 0.18 & 7.06 \\
\hline April & 7.42 & 5.4 & 18.6 & 420 & 225 & 225 & 165 & 0.16 & 3.08 \\
\hline July & 6.95 & 51.54 & 12.0 & 120 & 61 & 60 & 60 & 0.80 & 0.39 \\
\hline August & 7.20 & 53.23 & 09.0 & 130 & 63 & 50 & 55 & 0.85 & 0.33 \\
\hline September & 7.22 & 61.53 & 10.0 & 130 & 65 & 60 & 65 & 0.80 & 0.40 \\
\hline October & 7.06 & 31.52 & 18.5 & 135 & 67 & 60 & 65 & 0.40 & 0.41 \\
\hline November & 7.13 & 15.29 & 23.0 & 202 & 101 & 100 & 108 & 0.30 & 0.21 \\
\hline December & 7.42 & 7.30 & 18.0 & 326 & 163 & 156 & 145 & 0.11 & 1.25 \\
\hline
\end{tabular}

${ }^{*}$ Monthly average values are presented. NTU $=$ Nephelometric turbidity unit; TCU $=$ True colour unit; TDS $=$ Total dry solid; $\mathrm{NH}_{3}-\mathrm{N}=\mathrm{Ammonia-nitrogen}$

Table 2. Seasonal variation of physicochemical parameters of treated water of Saidabad Water Treatment Plant (SWTP) in the year 2004

\begin{tabular}{|c|c|c|c|c|c|c|c|c|c|c|c|}
\hline Month* & $\mathrm{pH}$ & $\begin{array}{l}\text { Turbidity } \\
\text { (NTU) }\end{array}$ & $\begin{array}{l}\text { Colour } \\
\text { (TCU) }\end{array}$ & $\begin{array}{c}\text { Conductivity } \\
(\mu \mathrm{S} / \mathrm{cm})\end{array}$ & $\begin{array}{l}\text { TDS } \\
(\mathrm{mg} / \mathrm{l})\end{array}$ & $\begin{array}{c}\text { Total } \\
\text { alkalinity } \\
\left(\mathrm{mg} / \mathrm{l} \text { as } \mathrm{CaCO}_{3}\right)\end{array}$ & $\begin{array}{c}\text { Total } \\
\text { hardness } \\
\left(\mathrm{mg} / \mathrm{l} \text { as } \mathrm{CaCO}_{3}\right)\end{array}$ & $\begin{array}{c}\mathrm{Fe} \\
(\mathrm{mg} / \mathrm{l})\end{array}$ & $\begin{array}{c}\mathrm{NH}_{3}-\mathrm{N} \\
(\mathrm{mg} / \mathrm{l})\end{array}$ & $\begin{array}{l}\text { Residual } \\
\mathrm{Cl}(\mathrm{mg} / \mathrm{l})\end{array}$ & $\begin{array}{c}\text { Total } \\
\mathrm{Cl}(\mathrm{mg} / \mathrm{l})\end{array}$ \\
\hline January & 7.31 & 0.92 & 4 & 400 & 201 & 168 & 158 & 0.02 & 2.91 & 0.31 & 4.6 \\
\hline March & 7.37 & 2.42 & 8.1 & 540 & 268 & 214 & 153 & 0.01 & 6.08 & 0.36 & 5.3 \\
\hline April & 7.28 & 0.54 & 5.4 & 460 & 232 & 165 & 133 & 0.02 & 2.57 & 0.30 & 4.0 \\
\hline May & 7.20 & 0.60 & 3.8 & 260 & 131 & 105 & 90 & 0.023 & 0.45 & 0.26 & 2.4 \\
\hline July & 7.25 & 0.36 & 1.7 & 150 & 71 & 51 & 65 & 0.02 & 0.02 & 0.29 & 0.51 \\
\hline August & 7.34 & 0.32 & 1.1 & 153 & 73 & 55 & 65 & 0.02 & 0.02 & 0.24 & 0.56 \\
\hline September & 7.29 & 0.27 & 1.0 & 148 & 74 & 56 & 69 & 0.03 & 0.01 & 0.24 & 0.48 \\
\hline October & 7.17 & 0.29 & 1.0 & 153 & 76 & 53 & 68 & 0.02 & 0.03 & 0.21 & 0.46 \\
\hline November & 7.17 & 0.29 & 1.0 & 224 & 112 & 73 & 88 & 0.01 & 0.01 & 0.23 & 0.45 \\
\hline December & 7.41 & 0.49 & 2.3 & 333 & 168 & 139 & 143 & 0.01 & 0.92 & 0.20 & 2.69 \\
\hline
\end{tabular}

*Monthly average values are presented. NTU = Nephelometric turbidity unit; TCU = True colour unit; TDS = Total dry solid; $\mathrm{NH}_{3}-\mathrm{N}=\mathrm{Ammonia}-\mathrm{nitrogen} ; \mathrm{Cl}=\mathrm{Chlorine}$

The conductivity, the total dry solid (TDS), alkalinity and total hardness of raw and treated water were stable from June through October, however, their levels were high during the rest of period (Table 1 and 2). The maximum and the minimum alkalinity recorded for the raw water were $230 \mathrm{mg} / \mathrm{l}$ in March and $50 \mathrm{mg} / \mathrm{l}$ in August respectively. The maximum (214 mg/l) and the minimum $(51 \mathrm{mg} / \mathrm{l})$ alkalinity of treated water were recorded in March and in July respectively. The conductivity of raw and treated water was low (120-153 $\mu \mathrm{S} / \mathrm{cm})$ during June through October, while it was high (250-540 $\mu \mathrm{S} / \mathrm{cm})$ during November through May. The TDS values of raw and treated water varied from 61 to $76 \mathrm{mg} / 1$ during June through October, and from 126 to $268 \mathrm{mg} / \mathrm{l}$ during November through May. The total hardness followed the same trend as with the alkalinity. The maximum and the minimum values hardness of raw water were 177 (in February) and $50 \mathrm{mg} / 1$ (in June) (Table 1). The maximum and the minimum hardness values of treated water were recorded in January-February $(158 \mathrm{mg} / \mathrm{l})$ and in June $(60 \mathrm{mg} / \mathrm{l})$ respectively (Table 2$)$. The hardness of both raw and treated water was conforms to the Bangladesh Standard $\left(200-500 \mathrm{mg} / \mathrm{l} \text { as } \mathrm{CaCO}_{3}\right)^{10}$.
Iron concentrations of the raw $(<1.0 \mathrm{mg} / \mathrm{l})$ and treated water $(<0.05$ $\mathrm{mg} / \mathrm{l})$ were found very low all over the year, which conform the WHO guidelines ${ }^{8}$. The overall ammonia-N value of treated water was lower than the raw water (Table 1 and 2). In raw water the ammonia-N was low (0.21-0.41 mg/l) during July through November, moderate $(1.09-1.25 \mathrm{mg} / \mathrm{l})$ in the months of May, June and December, and high (3.08-7.06 mg/1) during January through April. In treated water the ammonium-N value was low (0.01-0.54 $\mathrm{mg} / \mathrm{l})$ during May through November, moderate $(0.92 \mathrm{mg} / \mathrm{l})$ in December, and high (2.57-6.08 mg/l) during January through April. The upper limit for ammonium-N according to $\mathrm{WHO}^{8}$ and Bangladesh Standard ${ }^{10}$ are $1.5 \mathrm{mg} / \mathrm{l}$ and $0.5 \mathrm{mg} / \mathrm{l}$ respectively.

The level of free chlorine of the treated water was uniform all over the year, which varied between $0.20 \mathrm{mg} / 1$ (in December) and 0.36 $\mathrm{mg} / \mathrm{l}$ (in March). The total chlorine concentration was low (0.45$0.56 \mathrm{mg} / \mathrm{l})$ during July through November, and high (2.1-5.3 mg/l) during December through June. During chlorination of water containing $\mathrm{NH}_{3}$ in the treatment plant, various chloramines, viz., monochloramine $\left(\mathrm{NH}_{2} \mathrm{Cl}\right)$, dichloramine $\left(\mathrm{NHCl}_{2}\right)$ and trichloramine 
$\left(\mathrm{NCl}_{3}\right)$, are formed depending on the concentration of chlorine ${ }^{11}$. The chloramines are known as combined chlorine and are less active than hypochlorous acid (residual chlorine) at a magnitude of one-twentieth the power of hypochorous acid ${ }^{12}$.

Considering the bacteriological and physicochemical parameters, treated water of Saidabad Water Treatment Plant (SWTP) could be considered safe for domestic and drinking purpose for almost whole year. However, the level of ammonia-N in treated water was little elevated in the dry months that coincided with high level of ammonium contamination in the water of the river Sitalakhya. High concentration of ammonia in raw water coincided with increased load of coliforms, and that might also influenced the aesthetic properties like turbidity, colour, taste, odour, etc. of the treated water. Although raw water contained large number of coliforms but their counts in the treated water were well within the acceptable limit of WHO and Bangladesh Standard.

\section{References}

1. Ahmed MF. 1985. Waste disposal and degradation of waste quality in and around Dhaka city. In Proceedings of the Seminar on Protecting the Environment from Degradation. Science \& Technology Division, Ministry of Education. Government of People's Republic of Bangladesh, Dhaka, Bangladesh.
2. Anonymous. 1992. United Nations Conference on Environment and Development (1992). Earth Summit Agenda 21, Chapter 18. New York, USA.

3. Pipes WO. 1978. Bacterial Indicators of Pollution, $1^{\text {st }}$ edn, pp 2-24. CRC Press Ltd, Boca Ration, Florida.

4. APHA. 1998. Standard Methods for the Examination of Water and Wastewater (Greenberg AE, Clesceri LS \& Eaton AD eds), $20^{\text {th }}$ edn. American Public Health Association (APHA) Inc, Washington DC.

5. AWWA 1977. Simplified Procedure for Water Examination Laboratory Manual. American Water Works Association (AWWA), New York.

6. USEPA. 1979. Methods for Chemical Analysis of Water and Wastes. The United States Environmental Protection Agency (USEPA), Ohio.

7. Carter JA. 2005. Shift Sayedabad intake unit from Sarulia to Meghna for safe water. The Daily Star, January 28.

8. WHO. 1993.Guideline for Drinking Water Quality, Vol 1. Recommendations. World Health Organization (WHO), Geneva.

9. Reen CE. 2001. Investigating Water Problems: A Water Analysis Manual. Lamotte Chemical Products Company, Chestertown, Maryland.

10. BSTI. 1989. Bangladesh Standard Specification for Drinking Water, BDS 1240. Bangladesh Standard and Testing Institute (BSTI), Dhaka.

11. Angers J. 2002. What happens when ammonia occurs naturally in a chlorinated well? Opflow. American Water Works Association (AWWA), New York.

12. Cairncross S \& Feachem RG. 1983. Environmental Health Engineering in the Tropics: An Introductory Text, p 90. John Wiley \& Sons, New York. 